\title{
Mapping and genotypic analysis of the NK-lysin gene in chicken
}

\author{
Mi Ok Lee ${ }^{1}$, Ence Yang ${ }^{2}$, Mireille Morisson ${ }^{3,4,5}$, Alain Vignal ${ }^{3,4,5}$, Yong-Zhen Huang ${ }^{6}$, Hans H Cheng $^{7}$, \\ William M Muir ${ }^{8}$, Susan J Lamont ${ }^{9}$, Hyun Soon Lillehoj ${ }^{10}$, Sung Hyen Lee ${ }^{10}$ and James E Womack ${ }^{1 *}$
}

\begin{abstract}
Background: Antimicrobial peptides (AMP) are important elements of the first line of defence against pathogens in animals. NK-lysin is a cationic AMP that plays a critical role in innate immunity. The chicken NK-lysin gene has been cloned and its antimicrobial and anticancer activity has been described but its location in the chicken genome remains unknown. Here, we mapped the NK-lysin gene and examined the distribution of a functionally significant single nucleotide polymorphism (SNP) among different chicken inbred lines and heritage breeds.

Results: A 6000 rad radiation hybrid panel (ChickRH6) was used to map the NK-lysin gene to the distal end of chromosome 22. Two additional genes, the adipocyte enhancer-binding protein 1-like gene (AEBP1) and the DNA polymerase delta subunit 2-like (POLD2) gene, are located in the same NW_003779909 contig as NK-lysin, and were thus indirectly mapped to chromosome 22 as well. Previously, we reported a functionally significant SNP at position 271 of the NK-lysin coding sequence in two different chicken breeds. Here, we examined this SNP and found that the $A$ allele appears to be more common than the $G$ allele in these heritage breeds and inbred lines.

Conclusions: The chicken NK-lysin gene mapped to the distal end of chromosome 22. Two additional genes, AEBP1 and POLD2, were indirectly mapped to chromosome 22 also. SNP analyses revealed that the A allele, which encodes a peptide with a higher antimicrobial activity, is more common than the $\mathrm{G}$ allele in our tested inbred lines and heritage breeds.
\end{abstract}

\section{Background}

The chicken is an important animal for several reasons. In addition to being a major source of protein in the world, it is valuable to the understanding of genome evolution because of its relationship to mammals. The chicken genome sequence assembly was completed in 2004 with a six-fold whole genome shotgun (Sanger) coverage. It was the first avian genome to be sequenced [1] and, therefore, holds a place in comparative genomics as a prototypic avian genome. Subsequent sequencing and mapping have improved upon that first build, and efforts continue in search of missing and/or unassembled sequences, primarily on the smaller microchromosomes and the sex chromosomes. Nevertheless, sequence segments remain misplaced in the genome assembly [2] or unmapped.

\footnotetext{
*Correspondence: jwomack@cvm.tamu.edu

'Department of Veterinary Pathobiology, Texas A \& M University, College Station, TX 77843, USA

Full list of author information is available at the end of the article
}

Radiation hybrid (RH) panels are useful mapping tools to determine the location and order of genes, and to aid the assembly of genome sequences. RH panels are available for several domestic animal species including cow [3], pig [4], horse [5], dog [6], cat [7], mouse [8], chicken [9] and duck [10]. The ChickRH6 radiation hybrid panel was produced in 2002 [9] and has been used to construct consensus chromosome RH maps of the chicken genome and a limited number of chicken or GGA (Gallus gallus) chromosome maps have been published to date, namely GGA2 [11], GGA4 [12], GGA5 [13], GGA7 [14], GGA14 [15], GGA15 [16], GGA16 [17] and GGA25 [18].

NK-lysin is a cationic peptide with antibacterial activity that was originally isolated from porcine intestinal tissue. Extensive research has been conducted on the structure and antimicrobial activities of NK-lysin isolated from different species [19-23]. The chicken NK-lysin gene was cloned in 2006 [24], and its antimicrobial activity against Eimeria sporozocites was reported [25]. Previously, we identified a single nucleotide polymorphism (SNP) in the 
chicken NK-lysin gene and discovered that the encoded protein variants are differentially cytotoxic for several bacteria and cell lines derived from human cancers [26]. However, to date the location of NK-lysin on the chicken genome remains unknown. Here, we used the ChickRH6 panel to map the NK-lysin gene on the chicken genome, and also examined its polymorphism and allele distribution among diverse heritage breeds and inbred lines of chicken.

\section{Methods}

\section{Genotyping}

Different heritage chicken breeds available publically and several experimental inbred lines were surveyed. The heritage chicken breed samples came as pooled blood from eight to 26 animals, each. Three to seven individual samples were used for each inbred line. DNA (50 ng) was used for PCR amplification with a forward primer of cNKL QF3 and reverse primer of cNKL QR2 (Table 1), and Sanger sequencing was carried out with the BigDye Termination kit, version 1 (ABI, Foster City, CA). To estimate allele frequencies from pooled blood samples, mixtures of known amounts of pure A and G allele DNA at ratios of 1:0, 3:1, 2:1, 1:1, 1:2 and 0:1 were prepared as a standard reference for quantitative PCR products. The peak area and heights were measured to approximate the ratio of alleles in pooled DNA from the heritage breed samples.

Radiation hybrid panel genotyping and map construction The chicken NK-lysin gene was physically mapped using the INRA Chicken RH panel (ChickRH6) containing 90 hamster-chicken hybrid cell lines [9]. DNA from each line, along with control chicken and hamster DNA, were analysed for the presence or absence of NK-lysin and other markers by PCR (polymerase chain reaction) in 96-well microtiter plates. PCR was performed with the primers listed in Table 1. The PCR reactions were conducted with an initial denaturation step of $95^{\circ} \mathrm{C}$ for $5 \mathrm{~min}$, followed by 35 cycles of $95^{\circ} \mathrm{C}$ for $30 \mathrm{~s}, 62^{\circ} \mathrm{C}$ for $30 \mathrm{~s}, 72^{\circ} \mathrm{C}$ for $30 \mathrm{~s}$, and a final elongation step of $5 \mathrm{~min}$ at $72^{\circ} \mathrm{C}$. Each marker was run at least twice on the $\mathrm{RH}$ panel to insure reproducibility. The amplified product was typed and scored as present (1), absent (0), or ambiguous (2) as previously described [9].

Chromosome assignment was done and mapping was performed by including our genotyping data in a larger dataset composed of 10143 markers for the chicken genome. This dataset is composed of 2663 markers (genes and microsatellites) from the ChickRH database (http:// chickrh.toulouse.inra.fr) and 7480 SNPs genotyped on the ChickRH panel using the Illumina GoldenGate assay at the Centre National de Génotypage (CNG), Evry, France. RH mapping was conducted using the Carthagene software [27]. We assumed random breakage along the chromosomes and equi-probable retention of fragments. $\mathrm{RH}$ map was constructed in three steps: (1) a two-point analysis identified markers linked together with a LOD score greater than 8 and defined RH groups from these data; (2) using all the markers from the linkage group corresponding to GGA22, multipoint analyses were done to build a framework map using a LOD threshold of 3; and (3) additional markers were added by calculating their location relative to the framework markers. Finally the map design was created using MapChart 2.0 [28].

\section{Results}

\section{Single nucleotide polymorphism genotyping}

Previously, we identified a SNP at nucleotide 271 of the $N K$-lysin coding sequence and discovered that the encoded protein variants have different cytotoxicities for bacteria and anticancer activity [26]. Here, we genotyped this SNP among 32 heritage breeds and 10 inbred lines. The DNA from the heritage breeds was obtained from pooled blood samples from eight to 26 animals. We compared the A and G peak heights based on the sequencing

Table 1 Primer sequences used

\begin{tabular}{|c|c|c|c|c|}
\hline $\begin{array}{l}\text { Primer } \\
\text { pairs }\end{array}$ & $5^{\prime}=>3^{\prime}$ & $\begin{array}{l}\text { Size } \\
\text { (bp) }\end{array}$ & $\begin{array}{l}\mathrm{Tm} \\
\left({ }^{\circ} \mathrm{C}\right)\end{array}$ & $\begin{array}{l}\text { Reference for primers } \\
\text { GenBank accession number }\end{array}$ \\
\hline CNKL QF3 & GATGCAGATGAAGGGGACGC & 278 & 62 & NM_001044680 \\
\hline CNKL QR2 & CTGCCGGAGCTTCTTCAACA & & & \\
\hline NUDCD3 F & TCCTCTCTCCAAGTGCGTIT & 248 & 62 & XM_004947649 \\
\hline NUDCD3 R & TACACCTACACTCGCCAGCA & & & \\
\hline ADRA1A F & CTGTAGCCGACCTCCTCTTG & 182 & 62 & XM_425762 \\
\hline ADRA1A R & GCTCACCCCGATGTATCTGT & & & \\
\hline LRRTM4 F & GTTCTGCAGGAGTGGGGTTA & 165 & 62 & XM_004947641 \\
\hline LRRTM4 R & GGTAATGGGAGGCAACAAGA & & & \\
\hline SLC20A F & CAAAGTCAGCGAGACCAT CC & 218 & 62 & XM_003642557 \\
\hline SLC20A R & ATGGGAAGCTTCAAGAACGA & & & \\
\hline
\end{tabular}


chromatogram to estimate allele frequency (Figure 1). A single A peak was detected in eight breeds and a single $G$ peak was detected only in two of the 32 breeds (Table 2). Twenty-two of the 32 breeds analysed by pooled DNA revealed peaks for both A and G alleles. Eleven breeds showed A and $G$ chromatogram peaks of similar height, indicating that the frequencies of the A and $G$ alleles in the pooled DNA were approximately equal. Seven samples had a peak at least twice as high for allele A than for allele G. Only four of the 22 breeds carried $\mathrm{G}$ as the major allele. Thus, the A allele is more common than the $G$ allele across all tested heritage breeds (Table 2).

We also genotyped 10 inbred lines, eight from single animals and two from five pooled individuals. The White Leghorn line 6, Fayoumi M-5.1 and Fayoumi M-15.2 carried the $\mathrm{G}$ allele, while White Leghorn line 7, Leghorn Ghs-6, Leghorn Ghs-13, Spanish 21.1 and Leghorn line 8-15.1 carried the A allele. Two pooled inbred lines, line 0 and line 15Is, had the A allele (Table 3). There was no evidence of heterozygosity in any of the tested inbred lines. Thus, the A allele which has the higher antimicrobial activity was more common than the $\mathrm{G}$ allele across all tested heritage breeds and inbred lines.

\section{Mapping of the chicken NK-lysin gene}

In the Gallus_gallus-4.0 Primary Assembly, the unmapped contig NW_003779909 contains the chicken NK-lysin along with two additional genes, adipocyte enhancerbinding protein 1-like (AEBP1) and DNA polymerase delta subunit 2-like (POLD2). We used the $6000 \mathrm{rad}$ ChickRH6 panel to physically map the NK-lysin gene in the chicken genome. A retention frequency (RF) of $27.7 \%$ for NK-lysin was observed based on 25 positive PCR bands across the ChickRH6 panel. This RF value is within the range $(6.8 \%-55.7 \%)$ observed in other studies reported for this panel $[13,29,30]$.

Using two-point analysis, the NK-lysin gene was included in a linkage group of 104 markers corresponding to microchromosome GGA22. After multipoint analysis, the framework map was composed of 23 markers covering $351.8 \mathrm{cR}$. Three additional markers AEBP1, LRRTM4 (leucine-rich repeat transmembrane neuronal 4) and ADRA1A (adrenoceptor alpha 1A) were integrated at

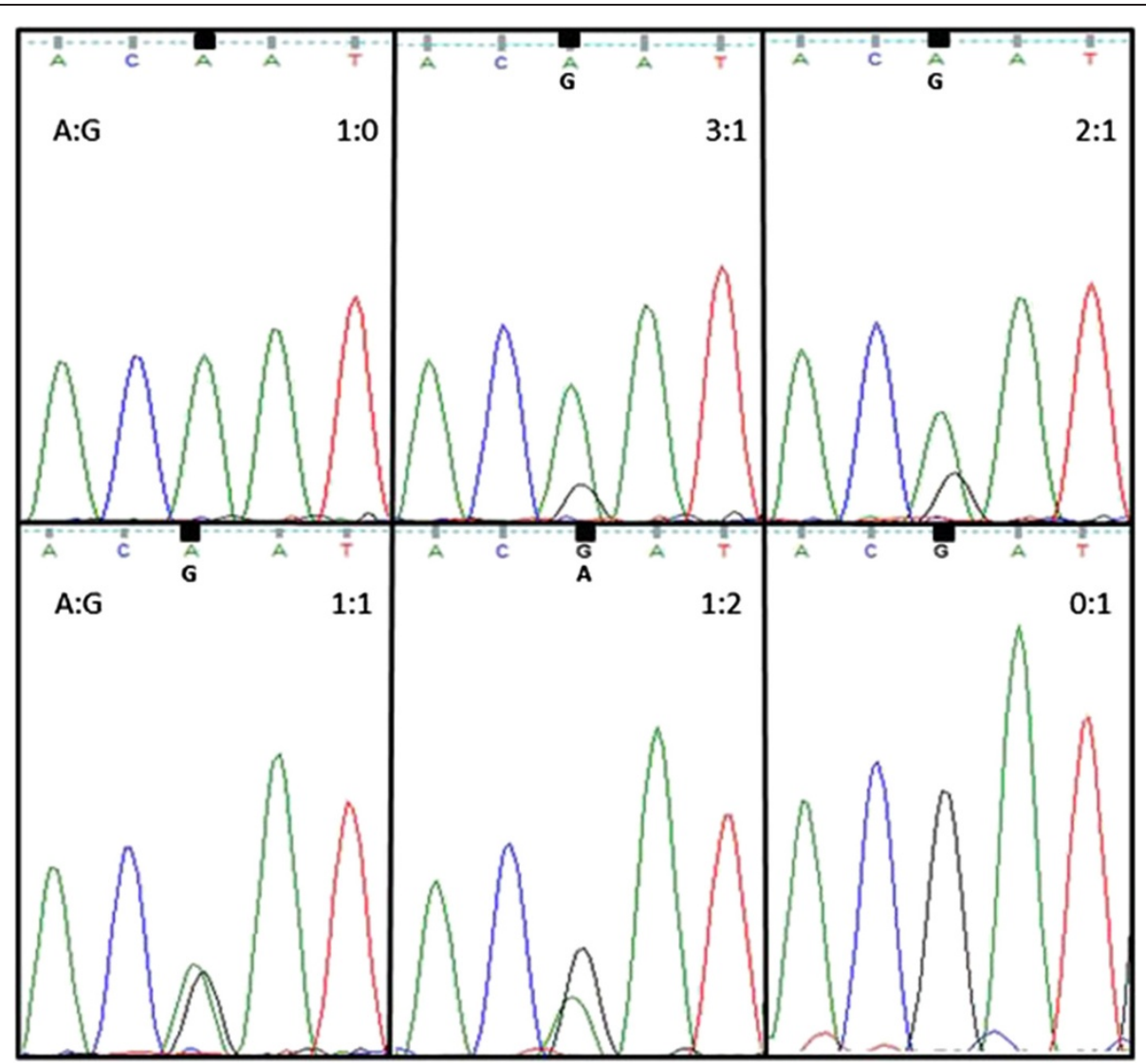

Figure 1 Sequencing chromatogram of pooled DNA. DNA from homozygous chicken (A and G allele) was mixed in 1:0, 3:1, 2:1, 1:1, 1:2 and 0:1 A to G ratios and used as PCR template and sequenced; each chromatogram peak was compared to peaks from pooled DNA samples of heritage breeds and shows the estimated $A$ to $G$ ratio. 
Table 2 Heritage breeds analyzed and their genotype

\begin{tabular}{|c|c|c|c|}
\hline Name of breeds & Company & $\mathrm{Nb}$ of animals (pooled) & Approximate ratio of $A: G$ \\
\hline New hamp red & Ideal Poultry & 18 & $2: 1$ \\
\hline Silver-gray dorking & Ideal Poultry & 8 & $1: 1$ \\
\hline Spangled russian orloff & Ideal Poultry & 18 & $1: 1$ \\
\hline Dark brahma & Ideal Poultry & 18 & $2: 1$ \\
\hline Standard blue cochin & Ideal Poultry & 16 & $1: 1$ \\
\hline Astd cornish stand & Ideal Poultry & 15 & $1: 0$ \\
\hline Dark aseel & Ideal Poultry & 17 & $3: 1$ \\
\hline BB red malay & Ideal Poultry & 16 & $1: 1$ \\
\hline Madagascar game & Ideal Poultry & 14 & $4: 1$ \\
\hline Black shamos & Ideal Poultry & 18 & $1: 1$ \\
\hline White rock & Ideal Poultry & 16 & $2: 1$ \\
\hline Blue andalusian & Ideal Poultry & 15 & $4: 1$ \\
\hline Gold phoenix & Ideal Poultry & 15 & $3: 1$ \\
\hline Red shoulder yoko & Ideal Poultry & 15 & $0: 1$ \\
\hline Crevecoeur & Ideal Poultry & 15 & $1: 0$ \\
\hline Asst japanese bantam & Ideal Poultry & 15 & $1: 1$ \\
\hline Rhode island red & Ideal Poultry & 18 & 1.1 \\
\hline Gams modern BB red & M McMurray Hatchery & 26 & $1: 0$ \\
\hline Sgdc silver gray dorkings & M McMurray Hatchery & 17 & $4: 1$ \\
\hline Sums sumatras & M McMurray Hatchery & 16 & $1: 0$ \\
\hline White faced black spanish & M McMurray Hatchery & 15 & $0: 1$ \\
\hline Dark cornish & Cackle & 15 & $1: 2$ \\
\hline Dominique standard & Cackle & 14 & $2: 1$ \\
\hline Silver duckwing standard phoenix & Cackle & 14 & $1: 0$ \\
\hline Blue cochin standard & Cackle & 17 & $1: 2$ \\
\hline White sultan & Cackle & 14 & $4: 1$ \\
\hline White crested black polish & Cackle & 13 & $1: 0$ \\
\hline German spitzhauben & Cackle & 15 & $1: 0$ \\
\hline Blue silkie bantam & Cackle & 16 & $1: 2$ \\
\hline Silver spangled hamburg & Cackle & 17 & $1: 0$ \\
\hline Saipan jungle fowl & Cackle & 11 & $2: 1$ \\
\hline Egyptian fayoumis & Cackle & 16 & $1: 2$ \\
\hline
\end{tabular}

Table 3 Inbred lines analyzed and their genotype

\begin{tabular}{lll}
\hline Name of line & Sources & Number of analysed animals \\
\hline Leghorn Ghs-6 & lowa State University & 3 \\
Leghorn Ghs-13 & lowa State University & 3 \\
Fayoumi M-5.1 & lowa State University and USDA-ARS Beltsville, MD & 7 \\
Fayoumi M-15.2 & lowa State University and USDA-ARS Beltsville, MD & 7 \\
Spanish 21.1 & lowa State University & 3 \\
Leghorn line 8-15.1 & lowa State University & 3 \\
Line O & USDA-ARS, East Lansing, MI & A Pooled 5 individuals \\
Line15ls & USDA-ARS, East Lansing, MI & Pooled 5 individuals \\
White leghorn line 6 & USDA-ARS Beltsville, MD & A \\
White leghorn line 7 & USDA-ARS Beltsville, MD & A \\
\hline
\end{tabular}


their best possible locations on the comprehensive map (Figure 2).

\section{Discussion}

SNPs are probably the most abundant genetic variants in animal genomes and these variations can be associated with or even underlie phenotypic traits, including disease susceptibility. Previously, we identified a SNP at nucleotide 271 of the NK-lysin coding sequence and discovered that the encoded protein variants have different properties and also different cytotoxicities for bacteria and anticancer activity [26].

The objective of this study was to map the NK-lysin gene in the chicken genome and to evaluate the distribution of the SNP alleles in common chicken breeds and inbred lines. Some breeds or lines were available only as pooled DNA from multiple animals of that line. However, quantitative analysis of pooled DNA samples is recognized as a legitimate approach to approximate allele frequencies of SNPs [31]. Thus, we analyzed the peak area and height of sequencing chromatograms and compared these to a reference standard of known amounts of mixed A and G allele DNA. Since allele frequencies can only be estimated, we are unable to conclude that any breed or line is fixed for either the A or G allele. We can, however, predict very low frequencies of the minor allele in breeds for which we only detected a single peak. These analyses revealed that the A allele is more common than the $G$ allele across all tested heritage breeds and inbred lines.

RH mapping analysis revealed that the NK-lysin gene is located in the distal region of chromosome GGA22. The $\mathrm{RH}$ map produced here is in agreement with the sequence assembly over the length of GGA22, extending it slightly with the addition of NK-lysin. Chromosome GGA22 is a microchromosome, approximately $4 \mathrm{Mb}$ long. Microchromosomes represent about one-third of the total avian genome size, and have been found to have a higher gene density than macrochromosomes [32]. Because microchromosomes are not easy to identify cytogenetically and because they lack microsatellite markers, it is difficult to localize genes on specific microchromosomes. Thus, many of the small linkage groups in the chicken genome that have not been placed on the genetic map or genome assembly are assumed to be located on the microchromosomes [32]. RH mapping analysis revealed that the $N K$-lysin gene was located very near to the NUDCD3 (NudC domain containing 3) gene on GGA22. Our data place NK-lysin, and the $10 \mathrm{~kb}$ contig NW_003779909, distal to $N U D C D 3$, the most telomeric gene marker in the sequence assembly. Its location near the telomere may explain the previous difficulty in placing this contig in the assembled chicken genome sequence.

Granulysin (GNLY), the human counterpart of NK-lysin, is located on human chromosome 2 between the genes SFTPB

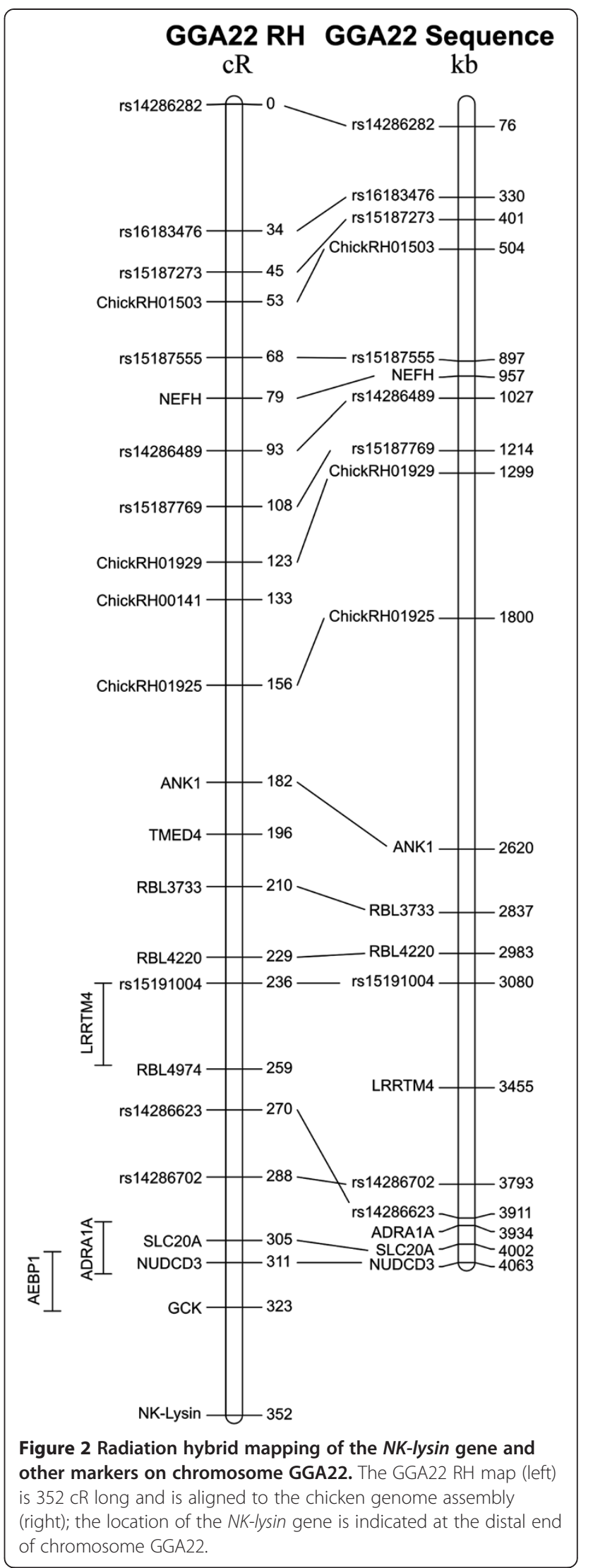


(surfactant-protein B) and ATOH8 (atonal homolog 8). This genomic organization is well conserved on cattle chromosome 11, pig chromosome 3 , horse chromosome 15, chimpanzee chromosome 2 and dog chromosome 17. While there is no known SFTPB gene in the chicken genome, the NUDCD3 gene at the telomeric end of GGA22 is located on human chromosome 7 and bovine chromosome 4. The chicken contig NW_003779909 contains the genes NK-lysin, AEBP1 and POLD2, which are all three located on the same human chromosome 7 and bovine chromosome 4 . Thus, a segment that contains these three mammalian genes is conserved in chicken, but the NKlysin gene disrupts the otherwise conserved synteny.

\section{Conclusions}

Previous reports have described the cloning of the chicken NK-lysin gene [24] and its antimicrobial and anticancer activity [26] but its location in the chicken genome was unknown. Here, we used ChickRH6 to localize the NK-lysin gene in the chicken genome at the distal end of GGA22. Two additional genes, $A E B P 1$ and POLD2, are located in the same NW_003779909 contig, and thus were also indirectly mapped to GGA22. Previously, we reported a functionally significant SNP in the NK-lysin coding sequence of two different chicken breeds. Here, we examined this SNP among a large number of different inbred lines and heritage breeds and found that the A allele, which has the higher antimicrobial activity, was more common than the $\mathrm{G}$ allele in our tested inbred lines and heritage breeds.

\section{Competing interests}

The authors declare that they have no competing interests.

\section{Authors' contributions}

$\mathrm{MOL}$ and JEW designed the experiment and $\mathrm{MOL}$, and $\mathrm{YH}$ performed initial RH mapping. HHC, WMM, SJL, HSL, SHL provided DNA and information on the origins of stocks and strains and contributed to writing the manuscript. MM, AV and EY constructed the refined GGA22 RH map and assigned NK-lysin. All authors have read and approved the final manuscript.

\section{Acknowledgements}

This work was supported by Basic Science Research Program through the National Research Foundation of Korea (NRF) funded by the ministry of education (2012R1A6A3A03039557).

\footnotetext{
Author details

'Department of Veterinary Pathobiology, Texas A \& M University, College Station, TX 77843, USA. ${ }^{2}$ Department of Veterinary Integrative Biosciences, Texas A \& M University, College Station, TX 77843, USA. ${ }^{3}$ INRA, UMR1388 Génétique, Physiologie et Systèmes d'Elevage, Castanet-Tolosan F-31326, France. ${ }^{4}$ Université de Toulouse INPT ENSAT, UMR1388 Génétique, Physiologie et Systèmes d'Elevage, Castanet-Tolosan F-31326, France. ${ }^{5}$ Université de Toulouse INPT ENVT, UMR1388 Génétique, Physiologie et Systèmes d'Elevage, Toulouse F-31076, France. ${ }^{6}$ College of Animal Science and Technology, Northwest A\&F University, Yangling, Shaanxi, People's Republic of China. 'USDA, ARS, Avian Disease and Oncology Laboratory, East Lansing, MI 48823, USA. ${ }^{8}$ Department of Animal Science, Purdue University, West Lafayette, IN 47907, USA. ${ }^{9}$ Department of Animal Science, lowa State University, Ames, IA 50011, USA. ${ }^{10}$ USDA, ARS, Animal Biosciences and Biotechnology Laboratory, Beltsville Agricultural Research Center, Beltsville, MD 20705, USA.
}

Received: 27 January 2014 Accepted: 13 May 2014

Published: 7 July 2014

\section{References}

1. International Chicken Genome Sequencing Consortium: Sequence and comparative analysis of the chicken genome provide unique perspectives on vertebrate evolution. Nature 2004, 432:695-716.

2. Morisson M, Denis M, Milan D, Klopp C, Leroux S, Bardes S, Pitel F, Vignoles F, Gerus M, Fillon V, Douaud M, Vignal A: The chicken RH map: current state of progress and microchromosome mapping. Cytogenet Genome Res 2007, 117:14-21.

3. Womack JE, Johnson JS, Owens EK, Rexroad CE 3rd, Schlapfer J, Yang YP: A whole-genome radiation hybrid panel for bovine gene mapping. Mamm Genome 1997, 8:854-856.

4. Yerle M, Pinton P, Robic A, Alfonso A, Palvadeau Y, Delcros C, Hawken R, Alexander L, Beattie C, Schook L, Milan D, Gellin J: Construction of a whole-genome radiation hybrid panel for high-resolution gene mapping in pigs. Cytogenet Cell Genet 1998, 82:182-188.

5. Chowdhary BP, Raudsepp T, Kata SR, Goh G, Millon LV, Allan V, Piumi F, Guerin G, Swinburne J, Binns M, Lear TL, Mickelson J, Murray J, Antczak DF, Womack JE, Skow LC: The first-generation whole-genome radiation hybrid map in the horse identifies conserved segments in human and mouse genomes. Genome Res 2003, 13:742-751.

6. Priat C, Hitte C, Vignaux F, Renier C, Jiang Z, Jouquand S, Cheron A, André C, Galibert F: A whole-genome radiation hybrid map of the dog genome. Genomics 1998, 54:361-378.

7. Menotti-Raymond M, David VA, Roelke ME, Chen ZQ, Menotti KA, Sun S, Schäffer AA, Tomlin JF, Agarwala R, O'Brien SJ, Murphy WJ: Secondgeneration integrated genetic linkage/radiation hybrid maps of the domestic cat (Felis catus). J Hered 2003, 94:95-106.

8. McCarthy LC, Terrett J, Davis ME, Knights CJ, Smith AL, Critcher R, Schmitt K, Hudson J, Spurr NK, Goodfellow PN: A first-generation whole genomeradiation hybrid map spanning the mouse genome. Genome Res 1997, 7:1153-1161.

9. Morisson M, Lemiere A, Bosc S, Galan M, Plisson-Petit F, Pinton P, Delcros C, Feve K, Pitel F, Fillon V, Yerle M, Vignal A: ChickRH6: a chicken wholegenome radiation hybrid panel. Genet Sel Evol 2002, 34:521-533.

10. Rao M, Morisson M, Faraut T, Bardes S, Feve K, Labarthe E, Fillon V, Huang Y, Li N, Vignal A: A duck RH panel and its potential for assisting NGS genome assembly. BMC Genomics 2012, 13:513.

11. Leroux S, Dottax M, Bardes S, Vignoles F, Feve K, Pitel F, Morisson M, Vignal A: Construction of a radiation hybrid map of chicken chromosome 2 and alignment to the chicken draft sequence. BMC Genomics 2005, 6:12.

12. Rabie TS, Crooijmans RP, Morisson M, Andryszkiewicz J, van der Poel JJ, Vignal A, Groenen MA: A radiation hybrid map of chicken Chromosome 4. Mamm Genome 2004, 15:560-569.

13. Pitel F, Abasht B, Morisson M, Crooijmans RP, Vignoles F, Leroux S, Feve K, Bardes S, Milan D, Lagarrigue S, Groenen MA, Douaire M, Vignal A: A highresolution radiation hybrid map of chicken chromosome 5 and comparison with human chromosomes. BMC Genomics 2004, 5:66.

14. Morisson M, Jiguet-Jiglaire C, Leroux S, Faraut T, Bardes S, Feve K, Genet C, Pitel F, Milan D, Vignal A: Development of a gene-based radiation hybrid map of chicken Chromosome 7 and comparison to human and mouse. Mamm Genome 2004, 15:732-739.

15. Morisson M, Leroux S, Jiguet-Jiglaire C, Assaf S, Pitel F, Lagarrigue S, Bardes S, Feve K, Faraut T, Milan D, Vignal A: A gene-based radiation hybrid map of chicken microchromosome 14: comparison to human and alignment to the assembled chicken sequence. Genet Sel Evol 2005, 37:229-251.

16. Jennen DG, Crooijmans RP, Kamps B, Acar R, van der Poel JJ, Groenen MA: Comparative map between chicken chromosome 15 and human chromosomal region 12q24 and 22q11-q12. Mamm Genome 2003, 14:629-639

17. Solinhac R, Leroux S, Galkina S, Chazara O, Feve K, Vignoles F, Morisson M, Derjusheva S, Bed'hom B, Vignal A, Fillon V, Pitel F: Integrative mapping analysis of chicken microchromosome 16 organization. BMC Genomics 2010, 11:616.

18. Douaud M, Feve K, Gerus M, Fillon V, Bardes S, Gourichon D, Dawson DA, Hanotte O, Burke T, Vignoles F, Morisson M, Tixier-Boichard M, Vignal A, Pitel F: Addition of the microchromosome GGA25 to the chicken genome sequence assembly through radiation hybrid and genetic mapping. BMC Genomics 2008, 9:129. 
19. Andersson M, Gunne $H$, Agerberth B, Boman A, Bergman T, Sillard R, Jornvall H, Mutt V, Olsson B, Wigzell H, Dagerlind A, Boman HG, Gudmundsson GH: NK-lysin, a novel effector peptide of cytotoxic T and NK cells. Structure and CDNA cloning of the porcine form, induction by interleukin 2, antibacterial and antitumour activity. EMBO J 1995, 14:1615-1625.

20. Pena SV, Hanson DA, Carr BA, Goralski TJ, Krensky AM: Processing, subcellular localization, and function of 519 (granulysin), a human late T cell activation molecule with homology to small, Iytic, granule proteins. J Immunol 1997, 158:2680-2688.

21. Wang Q, Bao B, Wang Y, Peatman E, Liu Z: Characterization of a NK-lysin antimicrobial peptide gene from channel catfish. Fish Shellfish Immunol 2006, 20:419-426.

22. Davis EG, Sang Y, Rush B, Zhang G, Blecha F: Molecular cloning and characterization of equine NK-lysin. Vet Immunol Immunopathol 2005, 105:163-169.

23. Espino $\mathrm{AM}$, Hillyer $\mathrm{GV}$ : Molecular cloning of a member of the Fasciola hepatica saposin-like protein family. J Parasitol 2003, 89:545-552.

24. Hong YH, Lillehoj HS, Dalloul RA, Min W, Miska KB, Tuo W, Lee SH, Han JY, Lillehoj EP: Molecular cloning and characterization of chicken NK-lysin. Vet Immunol Immunopathol 2006, 110:339-347.

25. Hong YH, Lillehoj HS, Siragusa GR, Bannerman DD, Lillehoj EP: Antimicrobial activity of chicken NK-lysin against Eimeria sporozoites. Avian Dis 2008, 52:302-305.

26. Lee MO, Kim EH, Jang HJ, Park MN, Woo HJ, Han JY, Womack JE: Effects of a single nucleotide polymorphism in the chicken NK-lysin gene on antimicrobial activity and cytotoxicity of cancer cells. Proc Natl Acad Sci USA 2012, 109:12087-12092.

27. de Givry S, Bouchez M, Chabrier P, Milan D, Schiex T: CARHTA GENE: multipopulation integrated genetic and radiation hybrid mapping. Bioinformatics 2005, 21:1703-1704.

28. Voorrips RE: MapChart: software for the graphical presentation of linkage maps and QTLs. J Hered 2002, 93:77-78.

29. Tian Y, Lu LZ, Fu Y, Tao ZR, Shen JD, Wang DQ, Yuan AP, Yin ZZ Assignment of $C C R 7$ gene to chicken chromosome 27 by radiation hybrid panel mapping. J Zhejiang Univ Sci B 2007, 8:314-317.

30. Tian Y, Lu L, Fu Y, Zhao J, Zhang C, Yuan Q, Shen J: Assignment of Dicer gene to chicken chromosome 5 by radiation hybrid panel mapping. Biochem Genet 2007, 45:239-243.

31. Olsson C, Liljedahl U, Syvanen AC: Quantitative analysis of SNPs in pooled DNA samples by solid-phase minisequencing. Meth Molec Biol 2003, 212:167-176.

32. Groenen MA, Cheng HH, Bumstead N, Benkel BF, Briles WE, Burke T, Burt DW, Crittenden LB, Dodgson J, Hillel J, Lamont S, Ponce de Leon A, Soller M, Takahashi H, Vignal A: A consensus linkage map of the chicken genome. Genome Res 2000, 10:137-147.

doi:10.1186/1297-9686-46-43

Cite this article as: Lee et al:: Mapping and genotypic analysis of the NK-lysin gene in chicken. Genetics Selection Evolution 2014 46:43.

\section{Submit your next manuscript to BioMed Central and take full advantage of:}

- Convenient online submission

- Thorough peer review

- No space constraints or color figure charges

- Immediate publication on acceptance

- Inclusion in PubMed, CAS, Scopus and Google Scholar

- Research which is freely available for redistribution

Submit your manuscript at www.biomedcentral.com/submit
C BioMed Central 